\title{
Privacy Pilfering At the Library
}

\author{
by Lee Ann Smith
}

\author{
"Swimming pools can be dangerous for children. \\ To protect them, one can install locks, put up fences, and deploy pool alarms. \\ All these measures are helpful, but by far the most important thing that one can do \\ for one's children is to teach them to swim." \\ --from the National Research Council's statement on "Youth, Pornography, and the Internet."
}

$\eta$

is a muggy, overcast summer day. The weather experts are promising afternoon thunderstorms. Going to the swimming pool is out of the question, but the library's Summer Reading Program is in full swing and there's going to be a magician performing this very afternoon. The mother of a twelve-year-old drops off her child at their public library branch for the magic show while she darts to the store for a few groceries. The self-conscious boy saunters into the library a little late. The show has already started and he glimpses into the program room to see a couple of his buddies and their parents caught up in the "disappearing handkerchief" trick. The stacks are quiet. His dad is at work and his mom is at the store. This is the moment he's been waiting for. The boy swallows hard, trying to get rid of the lump in his throat, and approaches the children's librarian. "Uhm, could you tell me where I can find books about bodies?" he asks shyly. It is a purposefully vague question, but the librarian is fairly sure she knows what he's looking for and unceremoniously leads the child to the 613 classification section. The child's eyes light up when he sees that she has taken him to the exact books he's looking for. The librarian retreats to the circulation desk.

Alone in the stacks, the child discovers answers to questions about his body, about girls, and about the "birds and bees" that he is too embarrassed to ask his parents. Five minutes before the magic show ends, he returns the books to the shelves and makes his way to the shark books. The magic show lets out and the boy's mother arrives. She picks up a Newsweek while she waits for him to find a shark book that he has not already read. He checks out several books and offers the librarian a nod of his head as a secret thank-you, not only for the information that she's led him to, but for the trust that he can place in her.

This story could have a very different ending. The stringent privacy policies of America's libraries are now being challenged. Imagine that the boy mentioned above is standing in front of the shark books and sees his mother come in, but instead of perusing a Newsweek, as she usually does, he notices that she's talking with the librarian who led him to the "body" books. A few minutes later the boy's mother pulls him from the stacks and reprimands him, so that all in the library can hear, for not attending the magic show and for "sneaking" into "birds and bees" books. Imagine again that the librarian in the second ending is following the law by revealing the boy's choice of books to his parent. If the privacy policies of libraries continue to be challenged, the strong trust that patrons have so long placed in libraries may soon be dissolved, resulting in fewer people using libraries, which will lead to less funding, which in turn will lead to fewer services.

\section{WHAT PRIVACY IS}

Privacy is "freedom from the intrusion of others in one's private life or affairs..." The "right to privacy" is not just a feel-good phrase coined by a few renegades and sporadically pulled out when convenience dictates its necessity. Privacy is an integral part of American culture and laws. The fourth, fifth, and ninth amendments of the Constitution of the United States of America guarantee the people against 
unreasonable searches and self-incrimination, promising that such rights shall not be denied. ${ }^{2}$

Since the 1930s librarians have taken privacy issues very seriously. Now, with electronic storage capabilities and automated systems that can store patron records indefinitely, protecting the privacy of its users is of utmost concern to many libraries. The American Library Association (ALA) monitors threats to patron confidentiality and keeps watch on organizations and government entities that may pose a threat to the trust between a library and its clientele. ${ }^{3}$

\section{WHY PRIVACY IS IMPORTANT TO LIBRARIES}

I have the right not to divulge information about myself to another. The library has the right, as well as the ethical obligation, not to divulge information about me or my reading habits, or the Internet sites I visit while I'm using the library computer, to anyone else. Even so, warrants or subpoenas can mean that the library will be legally obliged to disclose such information. Yet, revealing patron information, even if it is required by law, can cause patron confidentiality in the library to falter.

Fortunately, most libraries have developed and adhere to a privacy policy that follows the ALA Code of Ethics statement: "We protect each library user's right to privacy and confidentiality with respect to information sought or received and resources consulted, borrowed, acquired, or transmitted." This means that librarians have an ethical responsibility not to divulge any patron information to anyone. Legally, librarians are not bound by this privacy ethic and the American Library Association mandates no professional repercussions if it is not upheld. ${ }^{5}$ Most librarians, however, do tend to uphold this proclamation with firm conviction. Even so, this commitment to confidentiality is not "...meant to suggest that libraries should strive to protect terrorists and criminals from routine investigation. Libraries are not criminal sanctuaries, but educational ones. However, they have a responsibility to protect not only the freedom to read, but also the freedom to research."

\section{A COUPLE OF NOT-SO-PRIVATE CASES}

It is for purposes of national security, so we are told, that government agencies might want to know of someone's reading habits. In the 1956 case of the "Mad Bomber" in New York, police surveyed New York Public Library records for names of people who checked out books on explosives and demolition. They did not catch the bomber this way, but the incident caused librarians to consider seriously confidentiality issues.

As "reality" television shows attest, Americans have a penchant for voyeurism. This tendency is evident in the fascination that the media has with personal reading habits of someone who is accused of a crime. Consider the 1981 incident in which presidential assassin John Hinckley was found to have a library card and the Jefferson County Public Library (Colorado) was assailed with requests by journalists to see what Hinckley read. The librarian in charge refused these requests, but the county attorney maintained that circulation records were public and thus available to anyone. This decision was eventually overturned. ${ }^{8}$

\section{CHIPPING AWAY AT PRIVACY}

The ALA upholds and supports patrons' rights to privacy, but the ALA is not a legal entity. Thus, its Code of Ethics can be trumped by the law, as in the 1985 case of Sylvia Seegrist, who went on a shooting rampage, killing some and injuring other innocent people. Seegrist frequented the public library in Delaware County, Pennsylvania, and had visited it just a few hours before committing the murders. When called on to disclose Seegrist's reading habits to reporters and lawyers, the director of the Swarthmore Public Library refused and remained silent until a court order forced her to testify.

Such a seemingly simple constitutional right as the one not to divulge private information about individuals has been challenged in more recent years, especially since the September 11, 2001, terrorist attacks on the United States. The "Uniting and Strengthening America by Providing Appropriate Tools Required to Intercept and Obstruct Terrorism Act of 2001,” or the USA PATRIOT Act, was implemented 
hastily, just days after September 11, 2001. The Act does not allow for the normal safeguard of checks and balances, amends more than 15 statutes, was passed with little debate, and thus threatens basic civil liberties. ${ }^{10}$ This relates to libraries because the PATRIOT Act “...retains provisions appreciably expanding government investigative authority, especially with respect to the Internet. Those provisions address issues that are complex and implicate fundamental constitutional protections of individual liberty..."11

With the implementation of the USA Patriot Act, Americans' rights to privacy are being challenged like never before. Some even argue that the basic Bill of Rights guarantees of free speech, assembly, equal protection, and legal counsel are being ignored or outright defied. ${ }^{12}$

\section{CHILDREN'S RIGHTS BEING STRIPPED}

The loss of privacy protection is not something that just adults are dealing with. Clearly, laws that protect children should be in place. Children should by all means be safe from abuse and Internet predators. As though to emphasize that the casualty of security efforts is loss of privacy, laws that take away some privacy rights of children are now being implemented. Perhaps it is because of the 2001 terrorist attacks on the United States, because of the USA Patriot Act, because Americans are becoming more suspicious, because Americans feel as though we are losing control. It could be any of these reasons that has prompted Alaska to soon join seven other states by passing a bill that gives parents the right to view their children's library records. ${ }^{13}$

Judith Krug, who is director of the American Library Association's Office of Intellectual Freedom, contends that the proposed Alaskan law is distressing because "young people deserve some degree of privacy." Krug emphasizes that parents should talk with their children about what they have borrowed from the library. In other words, the lines of communication should be kept open. As Krug says, "Parents rushing to the legislature gives children a bad example, showing children they have no rights." ${ }^{14}$

\section{CONCLUSION}

Librarians are expected to respect the privacy of all people, be they adults or children. Librarians are not expected to make value judgments on whether honoring that privacy is the best thing for the individual situation. Indeed, the privacy of library patrons should be protected, and while respecting patron privacy is one of the noblest charges of librarians, this privacy should not be protected "at all costs."

If searching through a patron's library records can help police capture a killer or a child molester, then the police (not necessarily reporters and journalists and media gurus) should have access to those records. This is a controversial subject, but sometimes it seems that we are so busy trying to protect the guilty that the victims and the innocent suffer the most. A parent of a child who has been a crime victim should be outraged if police are denied access to something as seemingly innocuous as library records that could help in the capture of a perpetrator. Certainly, librarians must adhere to the Librarian's Code of Ethics, which dictates that librarians are to respect and uphold the privacy of the individual. If a rightful, legal request for library documents is made, however, librarians should not hesitate to offer helpful materials. This does not mean that librarians should readily provide information to anyone with a badge and an intimidating attitude. It means that librarians should give serious consideration to rightful, lawful requests for patron records.

The librarian in the first hypothetical scenario at the beginning of this paper was serving her young patron well. The librarian in the second ending of the scenario, by telling the boy's mother about his reading choices, was not only betraying a confidence in her young charge but also ignoring current rules of ethical conduct according to the ALA Code of Ethics. In fact, her actions could quite possibly cause the child to never set foot in a library again. Privacy is for the protection and well-being of all people, young or old.

In the popular children's book, The Three Little Wolves and the Big Bad Pig, ${ }^{15}$ the little wolves at first think they are protecting themselves from the "Big Bad Pig" by building bigger and more impenetrable houses that eventually have the look and feel of prisons. The Big Bad Pig is not able to "huff and puff and blow" the houses down, but he does destroy them with his sledgehammer, pneumatic drill, and dynamite. At last, the little wolves wise up and build themselves a beautiful house of flowers that "sways in the wind." The pig doesn't destroy it because the scent of the flowers is so nice, and in the end, all the characters learn to play (and live) together. As exemplified in The Three Little 
Wolves and the Big Bad Pig, we can be confined by "safety," or we can learn to use it to the utmost benefit.

\section{References}

${ }^{1}$ Random House Webster's College Dictionary, editor-in-chief Robert B. Costello (New York: Random House, Inc., 1992), 1073-1074.

2 "An Interpretation of the Library Bill of Rights," adopted June 19, 2002, by the ALA Council. $<$ http://www.ala.org/ala/oif/statementspols/statementsif/interpretations/privacy.htm> (June 15, 2004).

${ }^{3}$ Weiner, Robert G. "Privacy and Librarians: An Overview." <http://www.txla.org/pubs/tlj-1q97/privacy.html> (June 15, 2004).

${ }^{4}$ Code of Ethics, American Library Association. <http://www.ala.org/alaorg/oif/ethics.html> (June 15, 2004).

${ }^{5}$ Weiner.

${ }^{6}$ Pace, Andrew K., “Toward a More Practical Patriotism.” Published in Computers in Libraries, April 1, 2004, Vol. 24, Issue 4. <http:// search.epnet.com/direct.asp?an $=126483058 \mathrm{db}=\mathrm{afh}>($ June 15, 2004).

7 Weiner.

${ }^{8}$ Ibid.

${ }^{9}$ Weiner.

10 “The USA Patriot Act,” April 1, 2004. <http://www.epic.org/privacy/terrorism/usapatriot/> (June 15, 2004).

${ }^{11}$ Ibid.

${ }^{12}$ Solomon, Alisa, “Things We Lost in the Fire." Published in Village Voice, September 11-17, 2002. <http://www.villagevoice.com/issues/0237/solomon.php> (June 15, 2004).

${ }^{13}$ Minkel, Walter, "AK to Nix Kids' Privacy Rights." Published in School

Library Journal, April 2004, Vol. 50 Issue 4, p. 22. <http://search.epnet.com/direct.asp?an=12758492\&db=afh> (June 15, 2004).

${ }^{14}$ Ibid.

${ }^{15}$ Trivizas, Eugene. The Three Little Wolves and the Big Bad Pig, illus. Helen Oxenbury (New York: Margaret K. McElderrry Books, 1993).

\section{Selected Bibliograhpy}

"Code of Ethics," American Library Association. <http://www.ala.org/alaorg/oif/ethics.html> (June 15, 2004).

"An Interpretation of the Library Bill of Rights," adopted June 19, 2002, by the ALA Council. <http://www.ala.org/ala/oif/statementspols/ statementsif/interpretations/privacy.htm> (June 15, 2004).

Minkel, Walter, “AK to Nix Kids' Privacy Rights." Published in School Library Journal, April 2004, Vol. 50 Issue 4, p. 22. <http://search. epnet.com/direct.asp?an=12758492\&db=afh> (June 15, 2004).

National Research Council's, "Youth, Pornography, and the Internet" by the National Research Council, editors Dick Thornburgh and Herbert S. Lin. <http://www.ala.org/Template.cfm?Section=ifissues\&Template=/ContentManagement/ContentDisplay.cfm\& ContentID $=56821>($ June 15,2004$)$.

Pace, Andrew K., “Toward a More Practical Patriotism.” Published in Computers in Libraries, April 1, 2004, Vol. 24, Issue 4. $<$ http://search.epnet.com/direct.asp?an=12648305\&db=afh> (June 15, 2004).

Random House Webster's College Dictionary, editor-in-chief Robert B. Costello (New York: Random House, Inc., 1992), 1073-1074.

Solomon, Alisa, "Things We Lost in the Fire." Published in Village Voice, September 11-17, 2002. <http://www.villagevoice.com/ issues/0237/solomon.php> (June 15, 2004).

Trivizas, Eugene. The Three Little Wolves and the Big Bad Pig, illus. Helen Oxenbury (New York: Margaret K. McElderrry Books, 1993).

“The USA Patriot Act," April 1, 2004. <http://www.epic.org/privacy/terrorism/usapatriot/> (June 15, 2004).

Weiner, Robert G. "Privacy and Librarians: An Overview." < http://www.txla.org/pubs/tlj-1q97/privacy.html> (June 15, 2004). 